\title{
PREDICTION OF TURKEY'S ELECTRICITY GENERATION BY SOURCES USING ARTIFICIAL NEURAL NETWORK AND BIDIRECTIONAL LONG SHORT - TERM MEMORY
}

\author{
Batin Latif AYLAK ${ }^{1 *}$, Mehmet Hakan ÖZDEMIR ${ }^{2}$, Murat İNCE ${ }^{3}$, Okan ORAL ${ }^{4}$ \\ ${ }^{1}$ Turkish-German University, Faculty of Engineering, Department of Industrial Engineering, İstanbul, Türkiye \\ ${ }^{2}$ Turkish-German University, Faculty of Economic and Administrative Sciences, Department of Business \\ Administration, İstanbul, Türkiye \\ ${ }^{3}$ Isparta University of Applied Sciences, Vocational School of Technical Sciences, Department of Computer \\ Technologies, Isparta, Türkiye \\ ${ }^{4}$ Akdeniz University, Faculty of Engineering, Department of Mechatronics Engineering, Antalya, Türkiye
}

\begin{tabular}{l}
\hline Keywords \\
\hline Energy Generation, \\
Energy Sources, \\
Electrical Energy, \\
Artificial Neural Network, \\
Prediction.
\end{tabular}

\section{Abstract}

It is an indisputable fact that energy plays a big role in the development of countries. Electrical energy has a great share in the development. Electricity is a secondary energy source, i.e. it is obtained by transforming primary energy sources. Although the desired level has not yet been reached, Turkey's installed power has increased by years and a wide variety of energy sources such as coal, oil, natural gas, hydroelectric energy, wind, solar and other renewable energy sources are used in electricity generation. At this point, it is observed that the share of renewable energy sources in total electricity generation has increased from year to year. It should be underlined that this increase is very important for the country's economy. In this study, Turkey's electricity generation by sources for the years 2020 and 2021 was predicted with artificial neural network (ANN) and bidirectional long short term memory (BLSTM) methods using the data for electricity generation by sources in the years 2010-2019. The share of electricity generated from renewable energy sources in total electricity generation for 2020 by ANN and BLSTM methods was calculated as $18.08 \%$ and $18.6 \%$ respectively. For 2021 , the share of electricity generated from renewable energy sources in total electricity generation was calculated as $21.95 \%$ and $21.68 \%$ respectively. These results show that the share of electricity generated from renewable energy sources in total electricity generation will increase. Finally, suggestions were made on what kind of roadmap should be followed in the field of investments in renewable energy resources.

\section{TÜRKIYE'NIN KAYNAKLARA GÖRE ELEKTRIK ÜRETIMİNIN YAPAY SINIIR AĞI VE İKİ YÖNLÜ UZUN - KISA VADELİ BELLEK YÖNTEMLERİ KULLANILARAK TAHMINIİ}

\author{
Anahtar Kelimeler \\ Enerji Üretimi, \\ Enerji Kaynaklarl, \\ Elektrik Enerjisi, \\ Yapay Sinir A ğı, \\ Tahmin.
}

\begin{abstract}
Öz
Enerjinin ülkelerin gelişmesinde büyük bir rol oynadığı tartışılmaz bir gerçektir. Gelişmede elektrik enerjisine büyük pay düşer. Elektrik bir ikincil enerji kaynağıdır, yani birincil enerji kaynaklarının dönüştürülmesi sonucu elde edilmektedir. İstenen seviyeye ulaşılmamış olsa da Türkiye'nin kurulu gücü yıllara göre artmış ve elektrik üretiminde kömür, petrol, doğalgaz, hidroelektrik enerji, rüzgâr, güneş ve diğer enerji yenilenebilir enerji kaynakları gibi çok çeşitli enerji kaynakları kullanılmaktadır. Bu noktada toplam elektrik üretiminde yenilenebilir enerji kaynaklarının payının yıldan yıla arttığı gözlenmektedir. Bu artışın ülke ekonomisi için çok önemli olduğunun altı çizilmelidir. Bu çalışmada, Türkiye'nin 2010-2019 yllarındaki kaynaklara göre elektrik üretimi verilerinden yararlanılarak 2020 ve 2021 yılları için kaynaklara göre elektrik üretimi, yapay sinir ağı (Artificial Neural Network - ANN) ve iki yönlü uzun - kısa vadeli bellek yöntemleri (Bidirectional Long Short - Term Memory - BLSTM) ile tahmin edilmiştir. ANN ve BLSTM yöntemleriyle 2020 yllı için yenilenebilir enerji kaynaklarından üretilen elektriğin toplam elektrik
\end{abstract}

\footnotetext{
* ilgili yazar / Corresponding author: batin.latif@tau.edu.tr, +90-216-333-3127
} 
üretimi içindeki payının sırasıyla \%18,08 ve \%18,6 olacağı hesaplanmıştır. 2021 yılı için ise yenilenebilir enerji kaynaklarından üretilen elektriğin toplam elektrik üretimi içindeki payının sırasıyla \%21,95 ve \%21,68 olacağı hesaplanmıştır. Bu sonuçlar yenilenebilir enerji kaynaklarından üretilen elektriğin toplam elektrik üretimi içindeki payının artacağını göstermektedir. Son olarak yenilenebilir enerji kaynaklarına yatırımlar alanında nasıl bir yol haritası izlenmesi gerektiğine dair önerilerde bulunulmuştur.

Alıntı / Cite

Aylak, B. L., Özdemir, M. H., İnce, M., Oral, O. (2021). Prediction of Turkey’s Electricity Generation by Sources Using Artificial Neural Network and Bidirectional Long Short - Term Memory, Journal of Engineering Sciences and Design ,9(2), 425-435.

\begin{tabular}{l|l|l}
\hline Yazar Kimliği / Author ID (ORCID Number) & \multicolumn{3}{|l}{ Makale Süreci / Article Process } \\
\hline B. L. Aylak, 0000-0003-0067-1835 & Başvuru Tarihi / Submission Date & 29.01 .2021 \\
M. H. Özdemir, 0000-0002-7174-9807 & Revizyon Tarihi / Revision Date & 16.03 .2021 \\
M. İnce, 0000-0001-5566-5008 & Kabul Tarihi / Accepted Date & 30.03 .2021 \\
O. Oral, 0000-0002-6302-4574 & Yayım Tarihi / Published Date & 20.06 .2021 \\
\hline
\end{tabular}

\section{Introduction}

Energy sources are extremely important for economic and social development (Tunalı and Ulubaş, 2017). Humankind has needed energy since the earliest times and the demand for energy has increased gradually. This demand has been met by using a wide variety of energy sources (Yılmaz, 2012). There are various classifications for energy sources. One of these is the classification as non-renewable (fossil) sources and renewable sources (Koç and Şenel, 2013). While renewable energy sources mean energy sources that will not be exhausted in nature, nonrenewable energy sources mean energy resources that will be exhausted after a certain period of time even if they are present in nature currently.

Renewable energy sources are environmentally friendly, but obtaining energy from these sources is still more expensive and more limited. On the other hand, energy production from non-renewable energy sources creates harmful wastes and causes greenhouse gas emissions (Bekar, 2020). However, in the face of increasing demand, fossil fuels are used to a large extent because they are more comfortable in energy production and, as stated, less costly (Çınar and Yılmazer, 2015). The data in Table 1 reveal that fossil fuels are used to a large extent. In the source, where the data are taken, hydroelectric energy is shown separately from renewable energy.

Table 1. Primary energy consumption by fuels in exajoules (EJ) in the world in 2018 and 2019 (BP, 2020a)

\begin{tabular}{|l|c|c|c|c|}
\hline \multirow{2}{*}{ FUEL } & \multicolumn{2}{c}{2018} & \multicolumn{2}{c|}{2019} \\
\cline { 2 - 5 } & $\begin{array}{c}\text { ENERGY } \\
\text { CONSUMPTION }\end{array}$ & $\begin{array}{c}\text { SHARE } \\
(\%)\end{array}$ & $\begin{array}{c}\text { ENERGY } \\
\text { CONSUMPTION }\end{array}$ & SHARE (\%) \\
\hline OIL & 191.45 & 33.22 & 193.03 & 33.06 \\
\hline NATURAL GAS & 138.66 & 24.06 & 141.45 & 24.23 \\
\hline COAL & 158.79 & 27.56 & 157.86 & 27.04 \\
\hline NUCLEAR ENERGY & 24.16 & 4.19 & 24.92 & 4.27 \\
\hline HYDROELECTRIC & 37.34 & 6.48 & 37.66 & 6.45 \\
\hline RENEWABLES & 25.83 & 4.48 & 28.98 & 4.96 \\
\hline TOTAL & 576.23 & 100 & 583.90 & 100 \\
\hline
\end{tabular}

Another classification for energy sources is the classification made as primary and secondary energy sources (Koç and Kaya, 2015). Energy sources that can be used as they are in nature are called primary energy sources. Secondary energy sources are obtained by subjecting primary energy sources to various processes (Yapraklı and Yurttançıkmaz, 2012). Electricity can be generated by using various sources (Doğan, 2011). Therefore, electricity is a secondary energy source. However, electricity has an important place among energy sources. Electrical energy is applicable to many technologies, and it does not pollute the environment during its use. It has a wide field of consumption and an increase in electricity consumption was observed in parallel with developments in infrastructure investments in Turkey. Thus, the level of economic development of our country has also increased (Kar and Kınık, 2008). In 1902 electricity was generated in Tarsus district in Mersin for the first time by using a 2 kW dynamo connected to a water mill (Coşkun, 2012). Over time, installed power has increased and in parallel, 
electricity generation has also increased. As mentioned above, electrical energy can be generated by using various energy sources. Table 2 shows Turkey's electricity generation by sources for the period 2010-2019. (The numbers in Table 2 have been rounded up to four decimal places.) The column "Other renewables" include geothermal, biomass and other sources of renewable energy that are not already itemized. The column "Other" includes sources that are not specified elsewhere, e.g. pumped hydro, non-renewable waste and statistical discrepancies which can be positive or negative. As can be seen from Table 2, an increase in Turkey's electricity generation from year to year is observed. The very right column in Table 2 shows that the share of renewable energy sources in total electricity generation has increased from year to year.

Table 2. Turkey's electricity generation by sources in terawatt-hours (TWh) for the period 2010-2019

(BP, 2020b; BP, 2020c)

\begin{tabular}{|c|c|c|c|c|c|c|c|c|c|c|}
\hline \multirow{2}{*}{ YEAR } & \multirow{2}{*}{ OIL } & \multirow{2}{*}{$\begin{array}{l}\text { NATURAL } \\
\text { GAS }\end{array}$} & \multirow{2}{*}{ COAL } & \multirow{2}{*}{ HYDROELECTRIC } & \multicolumn{3}{|c|}{ RENEWABLES } & \multirow{2}{*}{ OTHER } & \multirow{2}{*}{$\begin{array}{c}\text { TOTAL } \\
\text { ELECTRICITY } \\
\text { GENERATION }\end{array}$} & \multirow{2}{*}{$\begin{array}{c}\text { SHARE OF } \\
\text { RENEWABLES } \\
\text { IN TOTAL } \\
\text { ELECTRICITY } \\
\text { GENERATION } \\
\text { (\%) }\end{array}$} \\
\hline & & & & & WIND & SOLAR & $\begin{array}{c}\text { OTHER } \\
\text { RENEWABLES } \\
\end{array}$ & & & \\
\hline 2010 & 2.1800 & 98.1437 & 55.0464 & 51.7955 & 2.9164 & 0.0024 & 1.0011 & 0.1246 & 211.2101 & 1.86 \\
\hline 2011 & 0.9036 & 104.0476 & 66.2179 & 52.3386 & 4.7239 & 0.0029 & 1.0371 & 0.1264 & 229.3979 & 2.51 \\
\hline 2012 & 1.6387 & 104.4992 & 68.0131 & 57.8650 & 5.8608 & 0.0043 & 1.4913 & 0.1288 & 239.5011 & 3.07 \\
\hline 2013 & 1.7388 & 105.1163 & 63.7861 & 59.4205 & 7.5575 & 0.0068 & 2.2422 & 0.2926 & 240.1607 & 4.08 \\
\hline 2014 & 2.1453 & 120.5760 & 76.2627 & 40.6447 & 8.5201 & 0.0174 & 3.4466 & 0.3501 & 251.9628 & 4.76 \\
\hline 2015 & 2.2239 & 99.2187 & 76.1656 & 67.1458 & 11.6525 & 0.1941 & 4.6655 & 0.5171 & 261.7834 & 6.31 \\
\hline 2016 & 1.9263 & 89.2271 & 92.2731 & 67.2309 & 15.5171 & 1.0431 & 6.4532 & 0.7369 & 274.4077 & 8.39 \\
\hline 2017 & 1.1999 & 110.4900 & 97.4763 & 58.2185 & 17.9038 & 2.8893 & 8.2515 & 0.8482 & 297.2775 & 9.77 \\
\hline 2018 & 0.3291 & 92.4828 & 113.2486 & 59.9385 & 19.9492 & 7.7998 & 10.0805 & 0.9734 & 304.8019 & 12.41 \\
\hline 2019 & 0.1690 & 58.1172 & 114.5633 & 89.1593 & 21.7040 & 10.9196 & 12.7106 & 1.1253 & 308.4683 & 14.70 \\
\hline
\end{tabular}

This study contributes a novelty to the literature with the feature of making the electricity generation prediction separately according to energy sources. In this study, Turkey's electricity generation by sources for the years 2020 and 2021 was predicted with artificial neural network (ANN) and bidirectional long short - term memory (BLSTM) methods using the data for electricity generation by sources in the years 2010-2019. Thus, it has been tried to predict which energy sources' share in electricity generation has increased or decreased. In this way, it was intended to shed light on investments in the energy field in Turkey.

This study consists of five sections. After the introduction, the second section includes a literature survey. In the third section, the material and method are explained, while the fourth section is devoted to the application. Finally, the fifth section contains results and discussion.

\section{Literature Survey}

There are many studies in the field of energy in which ANN is used to make predictions. Ringwood et al. (2001) forecasted short, medium and long term electricity demand for Ireland using ANN. Hsu and Chen (2003) formulated an ANN model to predict the regional peak load of Taiwan. Hamzaçebi and Kutay (2004) investigated the use of ANN in long-term electrical energy consumption forecasting. The results found with ANN were compared with those found by Box-Jenkins models and regression technique. The results have shown that ANN is a good forecaster of electrical energy consumption. Sözen et al. (2005) used two different ANN models to forecast net energy consumption in Turkey. In Model 1, population, gross generation, installed capacity and years are used in the input layer of the network. In Model 2, other energy sources are used in input layer of network. In both models, the net energy consumption is in the output layer. Pao (2006) used linear and nonlinear models including ANN to investigate the effect of national income, population, gross domestic production and consumer price index on the electricity consumption in Taiwan. It is shown that the ANN method is more suitable than the linear method for developing a electricity consumption forecasting model. Sözen et al. (2006) forecasted net energy consumption using the ANN technique. Population, gross generation, installed capacity and years are used in the input layer of network. The net energy consumption is in the output layer. Hamzaçebi (2007) forecasted Turkey's net electricity consumption on a sectoral basis using ANN because ANNs can forecast future values of more than one variable at the same time and model the nonlinear relation in the data structure. Sözen and Arcaklioglu (2007) used three 
different ANN models to predict net energy consumption in Turkey. In Model 1, installed capacity, generation, energy import and energy export are used in the input layer whereas gross national product in Model 2 and gross domestic product in Model 3 is used in the input layer of the network. For all models, the net energy consumption is in the output layer. Kavaklioglu et al. (2009) predicted electricity consumption of Turkey using ANNs. Electricity consumption is modeled as a function of population, gross national product, imports and exports. Geem and Roper (2009) proposed an ANN model to estimate the energy demand for South Korea. The model has gross domestic product, population, import and export amounts as independent variables. Kankal et al. (2011) modeled and forecasted Turkey's energy consumption based on socio-economic and demographic variables using ANN and regression analysis. Bilgili et al. (2012) applied ANN, linear regression and nonlinear regression models to estimate the electricity consumptions of the residential and industrial sectors in Turkey. Installed capacity, gross electricity generation, population and total subscribership are used as independent variables. Es et al. (2014) predicted the net energy demand of Turkey using ANN. Gross domestic product, population, imports, exports, building area and number of vehicles are used as inputs of the ANN model. Özden and Öztürk (2018) forecasted the energy demand in an industrial site (İvedik OSB) using ANN and time series method. Pençe et al. (2019) estimated the electricity consumption for the 2017-2023 period using an ANN model with data for the 1970-2016 period. In his master's thesis, Yüzük (2019) predicted Turkey's electricity consumption using multiple regression analysis and ANN with electricity data held on a monthly basis between the years 2010-2017. Kayakuş (2020) estimated Turkey's energy demand using ANN and support vector regression. 15 independent variables are used as inputs and Turkey's energy consumption value as the dependent variable is estimated.

\section{Material and Method}

In this study, Turkey's electricity generation by sources for the years 2020 and 2021 was predicted with ANN and BLSTM methods using the data for electricity generation by sources in the years 2010-2019. In this section, ANN and BLSTM methods are explained.

\subsection{Artificial Neural Networks}

ANNs are an artificial intelligence and machine learning method by imitating biological nerve cells (Esfe et al., 2015). ANNs generally contain an input layer, one or multiple hidden layers, and an output layer, neurons in these layers and weights (Figure 1). With this method, prediction and classification can be made with the aid of existing data. After training the system with real data, it is expected to obtain outputs suitable for the test data of the system. There is a large number of application areas for ANNs, i. e. skin cancer level determination (Esteva et al., 2017), detection of automobile engine faults (Ahmed et al., 2014), drug classification (Byvatov et al., 2003), electric load estimation (Park et al., 1991), stock market forecast (Ticknor, 2013), wind speed estimation (Khosravi et al., 2018) and electricity energy demand forecasting (Özden and Öztürk, 2018).

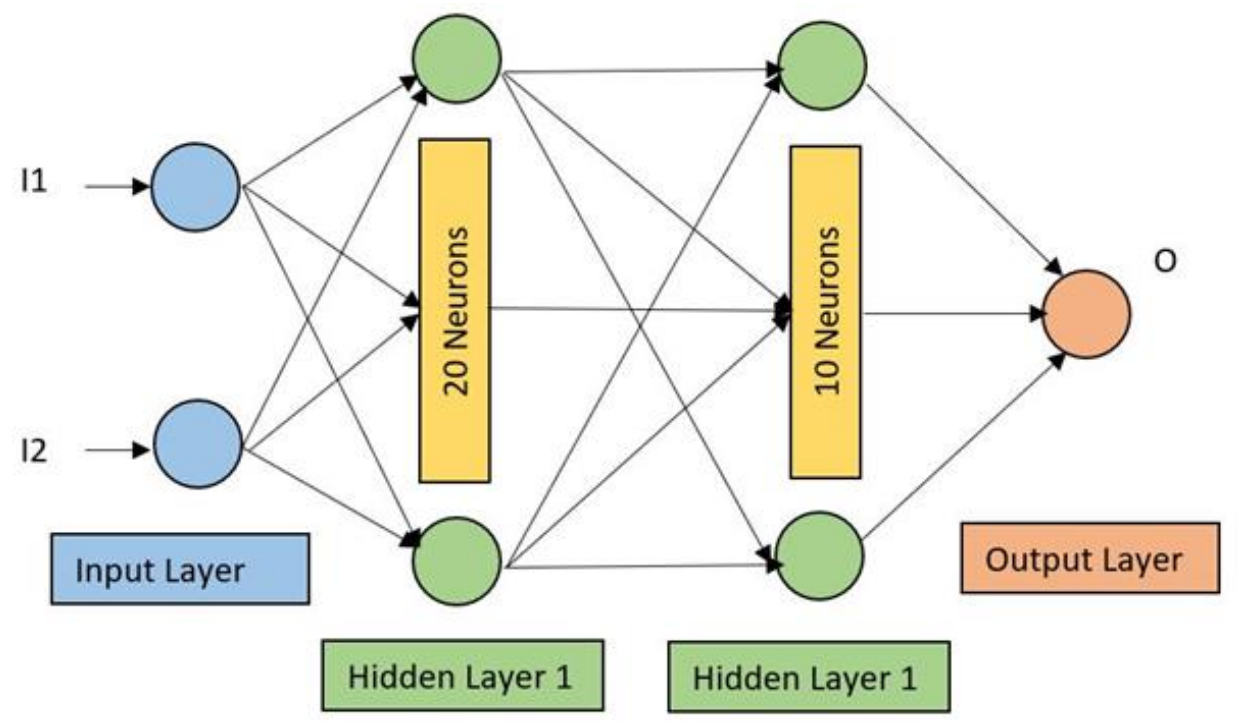

Figure 1. Network structure 2-20-10-1 


\subsection{Bidirectional Long-Short Term Memory}

Deep learning is another popular algorithm inspired by ANNs. Deep learning is used in many areas such as image processing, classification and natural language processing (Deng and Yu, 2014). Deep learning networks distinguish from classical ANNs in many ways, such as number of layers (LeCun et al., 2015). The most used deep learning algorithms are Convolutional Neural Network (CNN) and Recurrent Neural Network (RNN). A particular version of the regular RNN is Long-Short Term Memory. Normal (One-Way) LSTMs can fail in sequential operations such as time series since they do one operation (Graves and Schmidhuber, 2005). Bidirectional LSTMs run two LSTMs on the same input data in time series problems (Figure 2). The first LSTM runs on the input data from back to forward, while the second LSTM runs on the same data from forward to back (Kiperwasser and Goldberg, 2016). In this way, by running two LSTMs on the same input data, the system is provided to be faster and the learning deficiencies in one-way LSTM are completed.



Figure 2. BLSTM structure (Graves and Schmidhuber, 2005)

\section{Experimental Results}

In this study, Turkey's data on electricity generation from different sources for the period 2010-2019 are used to predict the electricity generation for the years 2020 and 2021. As the data were collected from an online database, an Ethics Committee Permission is not required in this study. Since the limited and one-dimensional data available are a time series, it is necessary to make use of historical data for prediction. Firstly, the data were transformed into a series with two elements. Then ANN and BLSTM methods were applied to these series.

In both methods, the values of electricity generated from oil in successive years in Table 2 were used as two inputs I1 and I2. The value of electricity generated from oil in the following year after these consecutive years was used as the only output $\mathrm{O}$ (Table 3). The values of I1, I2, and 0 in the first row in Table 3 are the values of electricity generated from oil for the years 2010, 2011 and 2012 respectively. While 12 in the first row is used as the first input in the second row, $\mathrm{O}$ in the first row is now used as the second input in the second row. This shifting is repeated for the remaining six rows. In other words, the values in the first row are from 2010, 2011, and 2012, respectively, while those in the second row are from 2011, 2012, and 2013. This process is continued until 2019. Thus, the data series to be used in the method is produced. In Tables 4-10, the data set was produced for other energy sources in the same way using the data in Table 2. 
Table 3. Two-element data set values of electricity generated from oil in the period 2010-2019

\begin{tabular}{|c|c|c|}
\hline $\mathbf{I 1}$ & $\mathbf{I 2}$ & $\mathbf{0}$ \\
\hline 2.1800 & 0.9036 & 1.6387 \\
\hline 0.9036 & 1.6387 & 1.7388 \\
\hline 1.6387 & 1.7388 & 2.1453 \\
\hline 1.7388 & 2.1453 & 2.2239 \\
\hline 2.1453 & 2.2239 & 1.9263 \\
\hline 2.2239 & 1.9263 & 1.1999 \\
\hline 1.9263 & 1.1999 & 0.3291 \\
\hline 1.1999 & 0.3291 & 0.1690 \\
\hline
\end{tabular}

Table 4. Two-element data set values of electricity generated from natural gas in the period 2010-2019

\begin{tabular}{|c|c|c|}
\hline I1 & I2 & 0 \\
\hline 98.1437 & 104.0476 & 104.4992 \\
\hline 104.0476 & 104.4992 & 105.1163 \\
\hline 104.4992 & 105.1163 & 120.5760 \\
\hline 105.1163 & 120.5760 & 99.2187 \\
\hline 120.5760 & 99.2187 & 89.2271 \\
\hline 99.2187 & 89.2271 & 110.4900 \\
\hline 89.2271 & 110.4900 & 92.4828 \\
\hline 110.4900 & 92.4828 & 58.1172 \\
\hline
\end{tabular}

Table 5. Two-element data set values of electricity generated from coal in the period 2010-2019

\begin{tabular}{|c|c|c|}
\hline I1 & I2 & 0 \\
\hline 55.0464 & 66.2179 & 68.0131 \\
\hline 66.2179 & 68.0131 & 63.7861 \\
\hline 68.0131 & 63.7861 & 76.2627 \\
\hline 63.7861 & 76.2627 & 76.1656 \\
\hline 76.2627 & 76.1656 & 92.2731 \\
\hline 76.1656 & 92.2731 & 97.4763 \\
\hline 92.2731 & 97.4763 & 113.2486 \\
\hline 97.4763 & 113.2486 & 114.5633 \\
\hline
\end{tabular}


Table 6. Two-element data set values of hydroelectricity generated in the period 2010-2019

\begin{tabular}{|c|c|c|}
\hline I1 & I2 & 0 \\
\hline 51.7955 & 52.3386 & 57.8650 \\
\hline 52.3386 & 57.8650 & 59.4205 \\
\hline 57.8650 & 59.4205 & 40.6447 \\
\hline 59.4205 & 40.6447 & 67.1458 \\
\hline 40.6447 & 67.1458 & 67.2309 \\
\hline 67.1458 & 67.2309 & 58.2185 \\
\hline 67.2309 & 58.2185 & 59.9385 \\
\hline 58.2185 & 59.9385 & 89.1593 \\
\hline
\end{tabular}

Table 7. Two-element data set values of electricity generation from wind in the period 2010-2019

\begin{tabular}{|c|c|c|}
\hline $\mathbf{I 1}$ & $\mathbf{I 2}$ & $\mathbf{0}$ \\
\hline 2.9164 & 4.7239 & 5.8608 \\
\hline 4.7239 & 5.8608 & 7.5575 \\
\hline 5.8608 & 7.5575 & 8.5201 \\
\hline 7.5575 & 8.5201 & 11.6525 \\
\hline 8.5201 & 11.6525 & 15.5171 \\
\hline 11.6525 & 15.5171 & 17.9038 \\
\hline 15.5171 & 17.9038 & 19.9492 \\
\hline 17.9038 & 19.9492 & 21.7040 \\
\hline
\end{tabular}

Table 8. Two-element data set values of solar electricity generated in the period 2010-2019

\begin{tabular}{|c|c|c|}
\hline I1 & I2 & $\mathbf{0}$ \\
\hline 0.0024 & 0.0029 & 0.0043 \\
\hline 0.0029 & 0.0043 & 0.0068 \\
\hline 0.0043 & 0.0068 & 0.0174 \\
\hline 0.0068 & 0.0174 & 0.1941 \\
\hline 0.0174 & 0.1941 & 1.0431 \\
\hline 0.1941 & 1.0431 & 2.8893 \\
\hline 1.0431 & 2.8893 & 7.7998 \\
\hline 2.8893 & 7.7998 & 10.9196 \\
\hline
\end{tabular}


Table 9. Two-element data set values of electricity generated from other renewables in the period 2010-2019

\begin{tabular}{|c|c|c|}
\hline $\mathbf{I 1}$ & $\mathbf{I 2}$ & $\mathbf{0}$ \\
\hline 1.0011 & 1.0371 & 1.4913 \\
\hline 1.0371 & 1.4913 & 2.2422 \\
\hline 1.4913 & 2.2422 & 3.4466 \\
\hline 2.2422 & 3.4466 & 4.6655 \\
\hline 3.4466 & 4.6655 & 6.4532 \\
\hline 4.6655 & 6.4532 & 8.2515 \\
\hline 6.4532 & 8.2515 & 10.0805 \\
\hline 8.2515 & 10.0805 & 12.7106 \\
\hline
\end{tabular}

Table 10. Two-element data set values of electricity generated from other sources in the period 2010-2019

\begin{tabular}{|c|c|c|}
\hline I1 & I2 & 0 \\
\hline 0.1246 & 0.1264 & 0.1288 \\
\hline 0.1264 & 0.1288 & 0.2926 \\
\hline 0.1288 & 0.2926 & 0.3501 \\
\hline 0.2926 & 0.3501 & 0.5171 \\
\hline 0.3501 & 0.5171 & 0.7369 \\
\hline 0.5171 & 0.7369 & 0.8482 \\
\hline 0.7369 & 0.8482 & 0.9734 \\
\hline 0.8482 & 0.9734 & 1.1253 \\
\hline
\end{tabular}

Different number of layers and neurons were tested in the training phase in order to obtain the best prediction in ANN method. Parameters, which give the best prediction, are chosen as ANN parameters. Thus, two inputs, one output and two hidden layers with 20 and 10 neurons respectively were used to form a network structure of 2 20-10-1 (Figure 1). Learning rate was adjusted as 0.5 and the sigmoid was used as activation function. It was carried out with 200 epochs during ANN training, and from the data for the years 2017 and 2018, a value of 0.1712362 was predicted for the actual value of 0.169 in 2019 with a relative error of $1.32 \%$ (Table 11). Then, BLSTM method was trained with 50 epochs, and Adam optimizer was used. Instead of the classical stochastic gradient reduction method, Adam is a more efficient, adaptive optimization algorithm, i.e. it updates the learning rate for each parameter (Kingma and $\mathrm{Ba}, 2014$; Ruder, 2016). By this method, a value of 0.170484 was predicted for the actual value of 0.169 in 2019 . A relative error of $0.88 \%$ has been found after comparing both values (Table 11). As can be seen in Table 11, the BLSTM method gives better results than the ANN method for all predictions of the value of electricity generated from various sources. 
Table 11. Predictions of the value of electricity generated from various sources in 2019

\begin{tabular}{|c|c|c|c|c|c|}
\hline \multirow{3}{*}{ SOURCE } & \multirow{3}{*}{$\begin{array}{l}2019 \text { ACTUAL } \\
\text { VALUE }\end{array}$} & \multicolumn{4}{|c|}{2019 PREDICTIONS } \\
\hline & & \multicolumn{2}{|c|}{ ANN } & \multicolumn{2}{|c|}{ BLSTM } \\
\hline & & VALUE & $\begin{array}{c}\text { RELATIVE } \\
\text { ERROR (\%) }\end{array}$ & VALUE & $\begin{array}{c}\text { RELATIVE } \\
\text { ERROR (\%) }\end{array}$ \\
\hline OIL & 0.1690 & 0.1712362 & 1.32 & 0.170484 & 0.88 \\
\hline NATURAL GAS & 58.1172 & 59.2442173 & 1.94 & 58.600586 & 0.83 \\
\hline COAL & 114.5633 & 113.9419604 & -0.54 & 115.013535 & 0.39 \\
\hline HYDROELECTRIC & 89.1593 & 61.2766661 & -31.27 & 69.08673 & -22.51 \\
\hline WIND & 21.7040 & 20.7803807 & -4.26 & 21.78258 & 0.36 \\
\hline SOLAR & 10.9196 & 10.689053 & -2.11 & 10.899599 & -0.18 \\
\hline $\begin{array}{l}\text { OTHER } \\
\text { RENEWABLES }\end{array}$ & 12.7106 & 12.0189666 & -5.44 & 12.6317005 & -0.62 \\
\hline OTHER & 1.1253 & 1.0572592 & -6.05 & 1.1144639 & -0.97 \\
\hline
\end{tabular}

ANN and BLSTM methods were used to predict the value of the electricity generated for 2020 from the data for 2018 and 2019 with the same training and optimization parameters (Table 12). Similarly, the value for 2019 and the predicted value for 2020 are used to predict the value of the electricity generated in 2021 from all different sources with the same training and optimization parameters (Table 12). The actual values for 2020 and 2021 are unknown.

Table 12. Predictions of the value of electricity in TWh generated from various sources for 2020 and 2021

\begin{tabular}{|l|c|c|c|c|}
\hline \multirow{2}{*}{ SOURCE } & \multicolumn{2}{|c|}{ 2020 PREDICTIONS } & \multicolumn{2}{c|}{ 2021 PREDICTIONS } \\
\cline { 2 - 5 } & ANN & BLSTM & ANN & BLSTM \\
\hline OIL & 0.21418289 & 0.2076833 & 0.25271984 & 0.2456418 \\
\hline NATURAL GAS & 65.23079431 & 65.27646 & 58.54790882 & 60.756832 \\
\hline COAL & 121.8642145 & 124.37067 & 129.5088635 & 138.93199 \\
\hline HYDROELECTRIC & 87.10565718 & 86.88384 & 91.94973769 & 93.227936 \\
\hline WIND & 24.7860188 & 26.758623 & 30.63023481 & 31.310879 \\
\hline SOLAR & 21.06665163 & 21.294617 & 30.84545502 & 31.787287 \\
\hline $\begin{array}{l}\text { OTHER } \\
\text { RENEWABLES }\end{array}$ & 14.97739043 & 15.445854 & 17.67159741 & 18.377289 \\
\hline OTHER & 1.11801605 & 1.1475525 & 1.13545079 & 1.1518936 \\
\hline TOTAL & 336.3629258 & 341.3852998 & 360.5419679 & 375.7897484 \\
\hline
\end{tabular}

As mentioned before, the BLSTM method yielded better predictions for the value of electricity generated from various sources in 2019 in comparison of the ANN method. Since the values for 2020 and 2021 are unknown, it cannot be determined which method gives better prediction values.

\section{Result and Discussion}

In this study, electricity generation by energy sources was predicted for 2020 and 2021 using ANN and BLSTM methods. According to analysis, it was observed that the BLSTM method gave better results than the ANN method in 2019 for all energy sources. Prediction values of electricity generation for 2020 and 2021 were calculated with the best ANN network structure and BLSTM parameters obtained from 2019 predictions.

As mentioned in the introduction, the share of electricity generated from renewable energy sources in total electricity generation is increasing year by year. This increase contributes to the Turkish economy by reducing 
foreign dependency. It is also a good development in terms of reducing the damage to the environment. Considering the predicted values obtained by both the ANN method and the BLSTM method for the years 2020 and 2021, it is observed that the share of electricity generated from renewable energy sources in total electricity generation has increased. According to the results found by ANN and BLSTM methods for 2020, it is predicted that the share of electricity generated from renewable energy sources in total electricity generation will be $18.08 \%$ and $18.6 \%$, respectively. For 2021, according to the results obtained by ANN and BLSTM methods, it is predicted that the share of electricity produced from renewable energy sources in total electricity generation will be $21.95 \%$ and $21.68 \%$, respectively. The outbreak, which has affected the whole world, may have a negative impact on the electricity generation. For this reason, it can be concluded that there is a difference between the total electricity generation value and the predicted value for 2020. Furthermore, fluctuations in hydroelectricity generation can be shown as another reason for the difference between the predicted value and the actual value in 2020 and 2021 .

In accordance with the goal of Affordable and Clean Energy, one of the Sustainable Development Goals of the United Nations, investments should be made in clean energy sources such as solar, wind and thermal energy in order to ensure that everyone can access energy by 2030. The necessity of investing into the field of renewable energy in Turkey has been confirmed by the results in this study.

Turkey has not only high solar energy potential but also high wind energy potential. In addition, it is practical and easy to generate electricity directly from these two energy sources. From this point of view, in future studies, especially the regions with high wind and solar energy potential can be determined and predictions for the electricity generation and the installed power in these regions can be made accordingly.

\section{Conflict of Interest}

No conflict of interest was declared by the authors.

\section{References}

Ahmed, R., El Sayed, M., Gadsden, S. A., Tjong, J., Habibi, S., 2014. Automotive internal-combustion-engine fault detection and classification using artificial neural network techniques. IEEE Transactions on vehicular technology, 64 (1), 21-33.

Bekar, N. (2020). Yenilenebilir Enerji Kaynakları Açısından Türkiye'nin Enerji Jeopolitiği. Türkiye Siyaset Bilimi Dergisi, 3 (1), 37-54.

Bilgili, M., Sahin, B., Yasar, A., Simsek, E., 2012. Electric energy demands of Turkey in residential and industrial sectors. Renewable and Sustainable Energy Reviews, 16 (1), 404-414.

BP British Petrol (2020a). Full Report - BP Statistical Review of World Energy 2020, https://www.bp.com/content/dam/bp/business-sites/en/global/corporate/pdfs/energy-economics/statisticalreview/bp-stats-review-2020-full-report.pdf (27.01.2021)

BP British Petrol (2020b). BP Statistical Review of World Energy - Overview documents - Consolidated dataset - panel format, https://www.bp.com/en/global/corporate/energy-economics/statistical-review-of-world-energy/downloads.html (27.01.2021)

BP British Petrol (2020c). BP Statistical Review of World Energy - Overview documents - Statistical Review of World Energy all data, 1965-2019, https://www.bp.com/en/global/corporate/energy-economics/statistical-review-of-worldenergy/downloads.html (27.01.2021)

Byvatov, E., Fechner, U., Sadowski, J., Schneider, G., 2003. Comparison of support vector machine and artificial neural network systems for drug/nondrug classification. Journal of chemical information and computer sciences, 43 (6), 1882-1889.

Coşkun, A., 2012. Türkiye'de Elektrik Enerjisi Sorunu ve Ekonomik Gelişmemizdeki Önemi. Sosyal Siyaset Konferansları Dergisi, (34), 73-83.

Çınar, S. Yılmazer, M., 2015. Yenilenebilir Enerji Kaynaklarının Belirleyicileri ve Ekonomik Büyüme İlișkisi: Gelișmekte Olan Ülkeler Örneği. Dokuz Eylül Üniversitesi İktisadi İdari Bilimler Fakültesi Dergisi, 30 (1), 55-78.

Deng, L., Yu, D., 2014. Deep learning: methods and applications. Foundations and trends in signal processing, 7 (3-4), 197-387.

Doğan, M., 2011. Enerji kullanımının coğrafi çevre üzerindeki etkileri. Marmara Coğrafya Dergisi, (23), 36-52.

Es, H. A., Kalender, F. Y., Hamzaçebi, C., 2014. Yapay sinir ağları ile Türkiye net enerji talep tahmini. Gazi Üniversitesi Mühendislik-Mimarlık Fakültesi Dergisi, 29 (3), 495-504.

Esfe, M. H., Saedodin, S., Sina, N., Afrand, M., Rostami, S., 2015. Designing an artificial neural network to predict thermal conductivity and dynamic viscosity of ferromagnetic nanofluid. International Communications in Heat and Mass Transfer, $68,50-57$.

Esteva, A., Kuprel, B., Novoa, R. A., Ko, J., Swetter, S. M., Blau, H. M., Thrun, S., 2017. Dermatologist-level classification of skin cancer with deep neural networks. Nature, 542 (7639), 115-118.

Geem, Z.W., Roper, W.E., 2009. Energy Demand Estimation of South Korea Using Artificial Neural Network, Energy Policy, 10, 6379-6380.

Graves, A., Schmidhuber, J., 2005. Framewise phoneme classification with bidirectional LSTM and other neural network architectures. Neural networks, 18 (5-6), 602-610.

Hamzaçebi, C., 2007. Forecasting of Turkey's net electricity energy consumption on sectoral bases. Energy policy, 35 (3), 2009 2016. 
Hamzaçebi, C., Kutay, F., 2004. Yapay Sinir Ağları ile Türkiye Elektrik Enerjisi Tüketiminin 2010 Yılına Kadar Tahmini, Gazi Üniversitesi Mühendis Mimarlık Fakültesi Dergisi, 19 (3), 227-233.

Hsu, C., Chen, C., 2003. Regional Load Forecasting in Taiwan Applications of Artificial Neural Networks, Energy Conversion and Management, 44, 1941-1949.

Kankal, M., Akpınar, A., Kömürcü, M. İ., Özșahin, T. Ș., 2011. Modeling and forecasting of Turkey’s energy consumption using socio-economic and demographic variables. Applied Energy, 88 (5), 1927-1939.

Kar, M., Kınık, E., 2008. Türkiye'de Elektrik Tüketimi Çeșitleri ve Ekonomik Büyüme Arasındaki İlișkinin Ekonometrik bir Analizi, Afyon Kocatepe Üniversitesi İ̈BF Dergisi, 10 (11), 333-353.

Kavaklioglu, K., Ceylan, H., Ozturk, H. K., Canyurt, O. E., 2009. Modeling and prediction of Turkey's electricity consumption using artificial neural networks. Energy Conversion and Management, 50 (11), 2719-2727.

Kayakuş, M., 2020. The Estimation of Turkey's Energy Demand Through Artificial Neural Networks and Support Vector Regression Methods. Alphanumeric Journal, 8 (2) , 227-236.

Khosravi, A., Koury, R. N. N., Machado, L., Pabon, J. J. G., 2018. Prediction of wind speed and wind direction using artificial neural network, support vector regression and adaptive neuro-fuzzy inference system. Sustainable Energy Technologies and Assessments, 25, 146-160.

Kingma, D. P., Ba, J., 2014. Adam: A method for stochastic optimization. arXiv preprint arXiv:1412.6980.

Kiperwasser, E., Goldberg, Y., 2016. Simple and accurate dependency parsing using bidirectional LSTM feature representations. Transactions of the Association for Computational Linguistics, 4, 313-327.

Koç, E., Kaya, K., 2015. Enerji Kaynakları - Yenilenebilir Enerji Durumu. Mühendis ve Makina, 56 (668), 36-47.

Koç, E., Şenel, M. C., 2013. Dünyada ve Türkiye'de enerji durumu-genel değerlendirme. Mühendis ve Makina, 54 (639), $32-44$.

LeCun, Y., Bengio, Y., Hinton, G., 2015. Deep learning. Nature, 521(7553), 436-444.

Özden, S., Öztürk, A., 2018. Yapay sinir ağları ve zaman serileri yöntemi ile bir endüstri alanının (İvedik OSB) elektrik enerjisi ihtiyaç tahmini. Bilişim Teknolojileri Dergisi, 11 (3), 255-261.

Pao, H., 2006. Comparing linear and nonlinear forecasts for Taiwan's electricity consumption. Energy, 31 (12), $2129-2141$.

Park, D. C., El-Sharkawi, M. A., Marks, R. J., Atlas, L. E., Damborg, M. J., 1991. Electric load forecasting using an artificial neural network. IEEE transactions on Power Systems, 6 (2), 442-449.

Pençe, İ., Kalkan, A., Şișeci Çeşmeli, M., 2019. Türkiye Sanayi Elektrik Enerjisi Tüketiminin 2017-2023 dönemi için Yapay Sinir Ağları ile Tahmini. Mehmet Akif Ersoy Üniversitesi Uygulamalı Bilimler Dergisi, 3 (2), 206-228.

Ringwood, J. V., Bofelli, D. Murray, F. T., 2001. Forecasting Electricity Demand on Short, Medium and Long Time Scales Using Neural Networks, Journal of Intelligent and Robotic Systems, 31, 129-147.

Ruder, S., 2016. An overview of gradient descent optimization algorithms. arXiv preprint arXiv:1609.04747.

Sözen, A., Akçayol, M. A., Arcaklioğlu, E., 2006. Forecasting net energy consumption using artificial neural network. Energy Sources, Part B, 1 (2), 147-155.

Sözen, A., Arcaklioglu, E., 2007. Prediction of net energy consumption based on economic indicators (GNP and GDP) in Turkey. Energy policy, 35 (10), 4981-4992.

Sözen, A., Arcaklioğlu, E., Özkaymak, M., 2005. Turkey’s net energy consumption. Applied Energy, 81 (2), 209-221.

Ticknor, J. L., 2013. A Bayesian regularized artificial neural network for stock market forecasting. Expert Systems with Applications, 40 (14), 5501-5506.

Tunalı, H., Ulubaș, M., 2017. Elektrik Enerjisi Tüketimi Ve Ekonomik Büyüme Arasındaki İlișki: G7 Ülkeleri Üzerine Bir Uygulama (1970-2015). Selçuk Üniversitesi Sosyal Bilimler Meslek Yüksekokulu Dergisi. 20 (1), 1-13.

Yapraklı, S., Yurttançıkmaz, Z. Ç., 2012. Elektrik tüketimi ile ekonomik büyüme arasındaki nedensellik: Türkiye üzerine ekonometrik bir analiz. Cumhuriyet Üniversitesi İktisadi ve İdari Bilimler Dergisi, 13 (2), 195-215.

Yılmaz, M., 2012. Türkiye'nin enerji potansiyeli ve yenilenebilir enerji kaynaklarının elektrik enerjisi üretimi açısından önemi. Ankara Üniversitesi Çevrebilimleri Dergisi 4 (2). 33-54.

Yüzük, F., 2019. Çoklu regresyon analizi ve yapay sinir ağları ile Türkiye enerji talep tahmini. (Master's thesis), Sivas Cumhuriyet Üniversitesi, Sivas. 